\title{
THE COSTS AND CONSEQUENCES OF US DRUG PROHIBITION FOR THE PEOPLES OF DEVELOPING NATIONS
}

\author{
J. Michael Blackwell*
}

\begin{abstract}
The widespread production and use of illicit drugs is a social phenomenon carrying enormous social, economic, and political significance. The United States stands as a vocal and forceful proponent of prohibitionist drug controls ${ }^{1}$ in international policymaking. However, strictly-enforced US prohibitionist drug controls largely fail to effectively reduce the consumption of narcotic drugs and ultimately create a significant number of negative consequences for many peoples throughout the world. The increased violence, government corruption, and community sequestration that result from the war against drugs are deleterious to economic development among rural communities in drug producing countries. In response to these concerns, this Article examines the purpose, effects, and consequences of the prohibitive drug controls routinely employed by the United States. Special attention is paid to an oftoverlooked repercussion of prohibitive drug controls: the marginalization of developmental human rights for peoples in drug producing countries.
\end{abstract}

* J.D., Indiana University Robert H. McKinney School of Law, 2013. A special thanks to family, friends, and Dr. Frank Emmert for guidance and support.

1. Jeffrey A. Miron, The Economics of Drug Prohibition and Drug Legalization, 68 Soc. Res. 2 (2001) [hereinafter The Economics of Drug Prohibition]. 


\section{INTRODUCTION}

The debate surrounding drug control policy in the United States is one of the most highly contested issues of recent decades. ${ }^{2}$ Narcotic drugs have long maintained a strong global presence and a significant impact on the lives of many peoples throughout the world. In response, a majority of nations embrace drug control policies that strictly prohibit the use and trade of narcotic drugs. ${ }^{3}$ The United States in particular stands as a vocal and forceful proponent of prohibitionist drug controls in international policymaking. ${ }^{4}$ Over the last forty years, the United States spent more than $\$ 2.5$ trillion on a number of activities, both domestic and abroad, aimed at decreasing the international flow of illicit drugs. ${ }^{5}$

Despite these efforts, empirical evidence indicates that these prohibitionist drug control policies fail to effectively reduce the consumption or production of drugs. Research suggests the worldwide number of drug users expanded throughout the past decade despite pervasive use of prohibitionist measures. ${ }^{6}$ The United Nations Office on Drugs and Crime (UNODC) estimates that, in 2010, between 153 million and 300 million people used illicit narcotics worldwide. ${ }^{7}$ In 2009, an estimated 8.7 percent of the US adult population (approximately 21.8 million people) used illicit drugs. ${ }^{8}$

This Article will show that the global implementation of strict prohibitionist drug control policies arguably yields many negative consequences for many peoples around the world, including increased

2. $I d$.

3. Philip Keefer et al., The Development Impact of the Illegality of Drug Trade 2 (The World Bank Policy Research Working Paper 4543, 2008), archived at http://perma.cc/65DG-9V89.

4. Melanie R. Hallums, Bolivia and Coca: Law, Policy, and Drug Control, 30 Vand. J. TRANSNAT'L L. 817, 843 (1997).

5. Brian Gilmore, Again and Again We Suffer: The Poor and the Endurance of the “War on Drugs," 15 UDC/DCSL L. REV. 59, 68 (2011).

6. Daniel Heilmann, The International Control of Illegal Drugs and the U.N. Treaty Regime: Preventing or Causing Human Rights Violations?, 19 CARDOZO J. INT'L \& COMP. L. 237, 261, 265 (2011).

7. U.N. Office on Drugs and CRime, World Drug Report 20127 (2012), archived at http://perma.cc/TS9G-GA24 [hereinafter WORLD DRUG REPORT 2012]. Since the 1990s, drug consumption of almost all types of illicit drugs has been on the rise. Joe Swanson, Drug Trafficking in the Americas: Reforming United States Trade Policy, 38 GEO. WASH. InT'L L. REV. 779, 781 (2006). Drug consumption has increased or remained steady in all categories of illicit drugs other than cocaine. Id.

8. See Press Release, Substance Abuse \& Mental Health Servs. Admin., National Survey Shows a Rise in Illicit Drug Use from 2008 to 2010 (Sept. 8, 2011) [hereinafter SAMHSA Press Release], archived at http://perma.cc/Q2DT-HFXZ; U.N. OFFICE ON DRUGS AND CRIME, WORLD DRUG REPORT 201113 (2011), archived at http://perma.cc/UKC3HRGT. 
violence among drug market participants, pervasive corruption of government agents, and crippling impairment of economic development among the world's underprivileged populations. This Article will also show that in the drug producing countries, prohibitionist policies encourage the destruction of private property and expropriate the wealth of poor farmers engaged in drug crop cultivation. Public safety and security are undermined, leaving entire nations weakened by the plague of corruption and violence that accompanies illicit drug activity.

While the modern drug control system may reduce potential harms associated with drug use, ${ }^{9}$ a strict prohibitive drug control system certainly creates additional costs and consequences for many peoples. Assessing the balance of these costs and any benefits is essential to affecting appropriate drug control measures and minimizing the negative impacts of drugs in society. This Article stresses the need for policymakers to comprehensively consider all costs and benefits of drug controls, as well as the costs and benefits of drug use itself.

Undeniably, the prevalence of drugs creates a number of individual and social costs for many peoples and societies: to some degree, regulation in the narcotic drug market is clearly necessary. Accordingly, this Article does not call for sweeping deregulation of the narcotic drug market. However, the imposition of a strict prohibitionist control system itself creates a great number of social costs. ${ }^{10}$ These costs must be equally and adequately considered if the current drug scheme is to be meaningfully improved.

This Article examines the purpose and effects of the prohibitive drug controls employed by the United States and the costs and consequences that result. Although this Article does not present a comprehensive account of all topics relevant to the prohibition conversation, it calls attention to a number of particularly important facts and perspectives that that are generally under-represented in drug control policymaking. Part II of this Article discusses the broad effects of drug consumption on society, the purposes of government drug controls, and an overview of prohibitionist drug control measures as they are implemented in international and US law. Part III applies a cost-benefit analysis to addresses the myriad problems stemming both from drug use and government-imposed drug controls. Special attention is called to an oft-overlooked consequence of the prohibitive drug model: the marginalization of developmental human rights for many peoples in drug producing countries. Finally, Part IV emphasizes the urgent need for the revision of US drug controls and offers a practical suggestion for reducing the harms currently stemming from prohibitionist activities.

9. The Economics of Drug Prohibition, supra note 1, at 5.

10. The Economics of Drug Prohibition, supra note 1, at 5. 


\section{THE FUNDAMENTAL DRUG PROBLEM}

The production and use of illicit drugs is a problem with enormous social, economic, and political significance. The UNODC estimates that, in 2010, between 153 million and 300 million people worldwide consumed illicit narcotics. ${ }^{11}$ The network of illegal drug trafficking that supplies these consumers is valued at more than $\$ 320$ billion annually and accounts for nearly 10 percent of all global trade. ${ }^{12}$ While cannabis, opiates, and cocaine are commonly identified as the main problem drugs, ${ }^{13}$ consumption of new synthetic drugs (e.g. ecstasy and methamphetamine) is steadily increasing. ${ }^{14}$ Although fluctuations in consumption patterns vary by geographic region, research suggests that the overall number of drug users has expanded worldwide throughout the last decade. ${ }^{15}$

North America is recognized as the world's largest consumer drug market, accounting for 44 percent of total global drug sales. ${ }^{16}$ According to the UNODC, approximately 1.1 percent of North American GDP in 2003, or $\$ 331$ per capita, is borne directly from the illicit drug trade. ${ }^{17}$ Drugrelated activity in the United States is particularly robust. In 2009, an estimated 8.7 percent of the US adult population used illicit drugs. ${ }^{18}$ In the United States, cannabis is by far the most commonly consumed narcotic. ${ }^{19}$ In 2008, 15.2 million people age twelve or older had used cannabis within the previous month. ${ }^{20}$ Cocaine, the second most commonly consumed illicit

11. World Drug Report 2012, supra note 7, at 7. Since the 1990s, drug consumption of almost all types of illicit drugs has been on the rise. Swanson, supra note 7, at 781. Drug consumption has increased or remained steady in all categories of illicit drugs other than cocaine. Id.

12. U.N. OfFice on Drugs ANd Crime, World Drug Report 2005127 (2005), archived at http://perma.cc/49YE-A3BG [hereinafter WORLD DRUG REPORT 2005]. Note that "[d]ue to the fact that in many instances the cultivation and production of drugs takes place in remote places and concealed settings, it is extremely hard to estimate the quantities of drugs produced." Heilmann, supra note 6 , at 259 . However, estimates are possible, and are provided by the UNODC. Heilmann, supra note 6, at 259.

13. Swanson, supra note 7, at 782 .

14. Kal Raustiala, Law, Liberalization \& International Narcotics Trafficking, 32 N.Y.U. J. INT'L L. \& POL. 89, 97 (1999).

15. Heilmann, supra note 6 , at 261. Heroin and opium use is reported to be increasing in the developing countries of Eastern Europe, Africa, and Asia. Heilmann, supra note 6, at 261. Also, while recent years have shown a decline in US cocaine consumption, the European market for cocaine is experiencing "a substantial expansion." Heilmann, supra note 6 , at 261 .

16. WORLD DRUG REPORT 2005, supra note 12, at 128.

17. WORLD DRUG REPORT 2005, supra note 12, at 129.

18. SAMHSA Press Release, supra note 8.

19. Sidney Weintraub \& Duncan Wood, Cooperative Mexican-U.S. ANTINARCOTICS EFFORTS 6 (2010), archived at http://perma.cc/8AA-7SRH.

20. Id. 
drug, was used by only 1.9 million individuals during the same period. ${ }^{21}$

The supply of narcotics is made available primarily through an international supply chain composed of transnational criminal organizations. While cannabis and amphetamine production occurs in over 170 countries, ${ }^{22}$ coca and opium crop cultivation is concentrated in only a small handful of countries, including Afghanistan, Colombia, Peru, and Bolivia. ${ }^{23}$ Significant drug transit pathways exist throughout much of Central America, West Africa, and the countries bordering Afghanistan. "Traffickers employ a wide range of land, air, and maritime methods for transporting illicit narcotics" including speed boats, shipping containers, submarines, small aircraft, commercial airlines, global mail delivery services, and ground transportation. ${ }^{24}$

Drug use is often cited as a flagrant social ill that spoils communities, hinders economic development, elevates crime rates, and burdens national public health infrastructures. ${ }^{25}$ Observers also suggest that "drug trafficking . . . represents a systemic threat to international security." ${ }^{26}$ In response to these costs, the majority of the world's governments prohibit the production and consumption of narcotic substances. ${ }^{27}$ In theory, these prohibitionist controls serve as non-monetary "taxes" that increase suppliers' costs, decrease the supply of drugs, and ultimately reduce the quantity of drugs consumed. ${ }^{28}$ The success of these measures largely depends on the relative

21. Id.

22. Peter Reuter \& Franz Trautmann, A Report on Global Drug Markets 1998200711 (2009).

23. Eur. Comm'n Directorate-General of Justice, Freedom and Security, A RePORt ON Global Illicit DRUg MARKets 1998-2007 11 (2009), archived at http://perma.cc/3WCG-68M7; Heilmann, supra note 6, at 260.

24. Liana Sun Wyler, Cong. Research Serv., RL 34543, International Drug CONTROL POLICY: BACKgROUND AND U.S. RESPONSES 6 (2013), archived at http://perma.cc/87BF-QWCA; see David Kushner, The Latest Way to Get Cocaine Out of Colombia? Under Water, N.Y. TIMES MAgazine, Apr. 26, 2009, at MM30, archived at http://perma.cc/VG8E-UKS8 (discussing the use of submarines in drug trafficking activities).

25. WYLER, supra note 24, at 6.

26. WYLER, supra note 24 , at 6.

27. Swanson, supra note 7, at 780. In an ideal world, drug control policy would "account for the fact that externalities created by drug use vary widely across individuals and drug type." Keefer et al., supra note 3, at 13. However, achieving such an ideal model is inherently difficult. In many societies, large segments of the population flatly reject the use of narcotic drugs, creating a social contempt that limits the creation of an ideal drug control policy. Philip Keefer et al., supra note 3, at 13. "Many States and international organizations, including both the United Nations and the United States, embrace a drug control regime that [highly estimates the negative externalities associated with drug use]." Keefer et al., supra note 3 , at 13 . Under such control systems, the production, trade, and use of narcotic drugs, are staunchly prohibited.

28. Jeffrey A. Miron, A Critique of Estimates of the Economic Costs of Drug ABUSE 17-18 (2003), archived at http://perma.cc/EEQ4-KWF6 [hereinafter MIRON 
price elasticity of the demand and supply of illicit drugs. ${ }^{29}$ Many factors affect the purchase preferences of drug consumers, including the severity of legal penalties, uncertainty about product quality, danger associated with illicit transactions, and the individual consumer's respect for the law. ${ }^{30}$ Similarly, the elasticity of drug supply is determined by such factors as the number of suppliers, availability of resources, and the costs of production relative to output. ${ }^{31}$

Substantial social science literature is dedicated to analyzing these factors, their effects on consumer behavior, and the imposition of prohibitive drug controls on the overall drug market. ${ }^{32}$ Although no definitive conclusion has yet been achieved, researchers largely indicate that drug prohibition has little or no effect on overall consumption of illicit drugs. ${ }^{33}$ But regardless of the quantity reduction that results, it is clear that the imposition of prohibitionist controls creates a black market for narcotic drugs. Many negative externalities result including corruption, extortion, and violence, seriously threatening the social, political, and economic stability of many nations and peoples. ${ }^{34}$

\section{A. Drug Prohibition Efforts within International Organizations}

Prohibitionist drug controls in international law are promulgated primarily through a series of United Nations conventions that set out a comprehensive strategy for controlling the narcotics trade. Three fundamental documents establish this framework: The Single Convention on Narcotic Drugs as amended by the 1972 Protocol, the Convention on Psychotropic Substances, and the United Nations Convention Against Illicit Traffic in Narcotic Drugs and Psychotropic Substances. ${ }^{35}$ Although these

CRITIQUE]. Drug prohibition creates trade barriers and criminal sanctions that dramatically increase the cost of doing business in the drug market. Id. Additional business expenses are also created, including bribery costs and the need to compensate employees for the risk of injury and incarceration. Id.; see also Gary S. Becker et al., The Economic Theory of Illegal Goods: The Case of Drugs 6 (National Bureau of Economic Research, Working Paper No. 10976, 2004). The case is similar with other underground economies including prostitution, the sale of goods to minors, and gambling, the illicit drug trade. Id. at 1. Supply restrictions generate scarcity, and boost the price to consumers. Heilmann, supra note 6, at 262; see also MIRON CRITIQUE, supra at 17.

29. Factors affecting Price Elasticity of Supply, DINESHBAKSH.COM, http://www.dineshbakshi.com/ib-economics/microeconomics/161-revision-notes/1709-

factors-affecting-price-elasticity-of-supply (last visited Dec. 31, 2012, archived at http://perma.cc/C8JY-4J7W).

30. Jeffrey A. Miron \& Jeffrey Zwiebel, The Economic Case Against Drug Prohibition, 9 J. OF ECON.PERSPECTIVES 175, 176 (1995).

31. Factors affecting Price Elasticity of Supply, supra note 29.

32. See the literature of Jeffrey Miron and progeny.

33. The Economics of Drug Prohibition, supra note 1, at $835,839$.

34. WYLER, supra note 24, at 6.

35. Heilmann, supra note 6 , at 239-240. The UN drug control system is managed by 
U.N. conventions "are part of a large body of international law that is not 'enforceable' in the traditional sense," their ratification obligates States to bring their domestic laws in line with treaty obligations. ${ }^{36}$ Signatories are subjected to diplomatic pressure, most notably from the United States, to refrain from enacting domestic laws in conflict with prohibitionist policies. $^{37}$

The U.N.-guided international drug control system is inherently interdependent with unilateral State efforts and numerous bilateral initiatives aimed at controlling the drug market. ${ }^{38}$ For instance, bilateral agreements between the United States and drug producing countries encourage "intelligence sharing, joint investigations, and the establishment of permanent task forces." ${ }^{39}$ Such initiatives include: the Mérida Initiative in Mexico; Central American Citizen Security Partnership; Caribbean Basin Security Initiative; US-Colombia Strategic Development Initiative; US Counternarcotics Strategy for Afghanistan; and West Africa Cooperative Security Initiative. ${ }^{40}$

Despite the threat of international diplomatic reprimand from prohibitionist countries, many nations embrace drug control policies that are less restrictive than the prohibitionist model. For example, personal drug consumption in the Netherlands, Switzerland, Italy, Spain, and Portugal is largely decriminalized. These nations refrain from embracing a prohibitionist system, and instead focus drug control efforts on reducing the harms that result from drug use. These harm reduction drug control efforts acknowledge drug use as an unstoppable "part of the human world, for better or worse" and render services for assisting drug users in reducing the harms of drug use itself. ${ }^{41}$ British Columbia also embraces a harm reduction drug control system by offering clinical programs such as safe injection sites, needle exchanges, and community health services to reduce the spread of deadly diseases like Hepatitis C and HIV/AIDS. ${ }^{42}$

In contrast to these harm reduction initiatives, a majority of nations embrace a prohibitionist drug control model. In many parts of the world, this strict prohibitionist regime provides a platform for egregious exploitation, oppression, and violence against citizens by criminal organizations and governments alike. In Mexico, for example, the war over drugs is a serious national problem that threatens the social and economic

three UN bodies: The Commission on Narcotic Drugs, the International Narcotics Control Board, and the UN Office on Drugs and Crime.

36. Kings County Bar Association, Effective Drug Control: Toward A New LEGAL FrAMEWORK n.203 (2005), archived at http://perma.cc/34YV-JW93 [hereinafter KINGS COUNTY BAR].

37. Id.

38. Heilmann, supra note 6 , at 257.

39. Heilmann, supra note 6 , at 258.

40. WYLER, supra note 24, at "Summary."

41. Kings COUNTY BAR, supra note 36, at n.260.

42. KINGS COUNTY BAR, supra note 36 , at n.265. 
stability of the nation. Increased competition among Mexican cartels has increased drug trafficking wildly along Mexico's Northern border, turning drug-related crime into a rampant problem. ${ }^{43}$ As alliances shift between gangs of cartel operatives, innocent civilians are caught in the crossfire between cartel gunmen and law enforcement officials. These conflicts have contributed to the doubling of the Mexican crime rate since the early 1990s, including increased kidnappings, bribery of government officials, and drugrelated violence. $^{44}$

Mexican law enforcement activities have in many ways exacerbated the issues surrounding narcotic drugs and produced a significant number of human rights violations. Oftentimes, corrupt law enforcement officials deliberately fail to enforce laws against narcotics traffickers. ${ }^{45}$ Also, some uncorrupt but overzealous police officers ignore the human rights of individuals suspected of drug-related crimes. Many times, local Mexican police officers and the judiciary work under the employ of the drug cartel and ultimately ensure the continued presence of narcotics trade in Mexico. ${ }^{46}$

Drug control problems also persist in East Asia, where strict drug enforcement laws often allow for the extrajudicial killing of drug market participants. Hundreds of people are executed annually for violating drug laws in many nations including Vietnam, Singapore, Malaysia, China, Iran, and Saudi Arabia. In the Philippines, "death squads" routinely kill persons suspected by the Philippine Drug Enforcement Agency of drug-related activity. ${ }^{47}$ In Singapore, the Misuse of Drugs Act provides a mandatory death sentence for trafficking small quantities of narcotics, and is cited by the Singapore Court of Appeal as justification for the execution of a nineteen-year-old man convicted of peddling forty-two grams of diamorphine. ${ }^{48}$ The Chinese government publicly executed more than fifty people in a single week to support the United Nation's "Anti-Drugs Day."

43. Jeremiah E. Goulka, A New Strategy For Human Rights Protection: Learning From Narcotics Trafficking In Mexico, 9 CARDOZO J. INT'L \& COMP. L. 231, 234 (2001).

44. Id. at 235. Estimates suggest that upwards of 500 kidnappings occur in Mexico every year. $I d$. Mexican traffickers spend "more than sixty percent of their $\$ 10$ billion annual revenue paying bribes." $I d$. at 236 . Since 2006 , more than 60,000 people have been killed in drug-related violence in the border city of Ciudad Juárez alone. Q\&A: Mexico's DrugRelated Violence, BBC News (Dec. 24, 2012), http://www.bbc.co.uk/news/world-latinamerica-10681249, archived at http://perma.cc/MZG2-F4PJ.

45. Ted Galen Carpenter, Corruption, Drug Cartels and the Mexican Police, CATO INSTITUTE (Sept. 4, 2012), http://www.cato.org/publications/commentary/corruption-drugcartels-mexican-police, archived at http://perma.cc/CC4D-PGJZ.

46. Goulka, supra note 43, at 238.

47. KingS COUNTY BAR, supra note 36 , at n.238.

48. Misuse of Drugs Act, Cap. 185, (2008) (Singapore), archived at http://perma.cc/9XLZ-FADP; see also KINGS COUNTY BAR, supra note 36, at nn.239-240.

49. Kings COUnTY BAR, supra note 36, at n.243. 


\section{B. United States Prohibitionist Drug Control Regime}

The United States stands as the most vocal and forceful proponent of prohibitionist drug controls in international policymaking. ${ }^{50}$ Over the last forty years, the United States spent over $\$ 2.5$ trillion on prohibitive drug control activities. ${ }^{51}$ The United States maintains the highest incarceration rate in the world, a statistic due in no small part to the aggressive implementation of prohibitionist policies. ${ }^{52}$

\section{Domestic drug Enforcement Efforts}

Modern drug control efforts in the United States began in the late nineteenth century with the prohibition of domestic manufacture or import of opium products. ${ }^{53}$ Subsequent changes in the social and political climate of the early twentieth century allowed Congress to expand its police powers and establish a foundation for drug prohibition that extends to present day. Throughout the twentieth century, US lawmakers continued to expand the prohibitionist drug control system, enacting additional drug laws to prohibit drug-related activity, including both the manufacture and recreational use of drugs. ${ }^{54}$ US anti-drug efforts like the "Reefer Madness" campaign of the 1930s aimed to demonize cannabis, promote biases against racial minorities, and snub out the cannabis industry. ${ }^{55}$ A number of federal drug control laws were enacted to snub out drug consumption, including the Boggs Act of 1951, ${ }^{56}$ Narcotic Control Act of 1956, ${ }^{57}$ and the Drug Abuse Control Act of $1965 .^{58}$

50. Hallums, supra note 4, at 843.

51. Gilmore, supra note 5, at 68.

52. Gilmore, supra note 5, at 73.

53. Kings COUNTY BAR, supra note 36, at nn.88-90.

54. Kings COUnTY BAR, supra note 36, at n.110. The Harrison Act required all manufactures of narcotics to register their activity with the federal government and pay a tax on all transactions, limiting the availability of opium and cocaine for non-medical recreational purposes. KINGS COUNTY BAR, supra note 36, at n.117. Opium Exclusion Act was the first federal drug law serving as a message of US intolerance toward recreational drug use. KINGS COUNTY BAR, supra note 36, at n.111.

55. Kings COUNTY BAR, supra note 36, at n.148.

56. Kings COUNTY BAR, supra note 36, at n.148.

57. Kings COUNTY BAR, supra note 36, at n.164.

58. The Boggs Act imposed the nation's first mandatory minimum sentences for drugrelated convictions. KINGS COUNTY BAR, supra note 36, n.161. The Narcotic Control Act of 1956 (Daniel Act) increased prison terms and fines for violations of narcotics laws. KINGS COUNTY BAR, supra note 36, at n.165. The Daniel Act also added a death penalty provision for selling heroine to persons under the age of 18. KINGS COUNTY BAR, supra note 36, at n.165. The Drug Abuse Control Act of 1965 established the Bureau of Drug Abuse Control, charging the Food and Drug Administration with enforcement responsibility, but was largely unsuccessful in decreasing drug use. KINGS COUNTY BAR, supra note 36, at n.170. 
In the early 1970s, President Nixon took drug prohibition efforts to new heights. In 1969, the Nixon administration embarked on a global campaign against drug trafficking by launching a series of anti-drug policy actions colloquially known as the "War on Drugs." 59 These public campaign efforts served as an effective accompaniment to the Controlled Substances Act (CSA), enacted by the United States Congress in 1970. ${ }^{60}$ The CSA replaced all previously existing federal drug laws and marked the beginning of the modern drug control era. ${ }^{61}$ To this day, the CSA is the primary piece of federal legislation directing drug enforcement activities in the United States, including crop eradication, border inspections, drug screenings in prison, and control of precursor chemicals. ${ }^{62}$ In the decades since, US policymakers largely supported a strict approach to drug control, issuing a series of anti-drug laws to update the CSA. ${ }^{63}$ As a result, current drug laws embrace a schedule of strict punishment for drug offenses, including mandatory minimum sentences and the availability of the death penalty for certain drug-related crimes. ${ }^{64}$

Despite these strict federal drug laws, wide variation still exists among the specific drug policies embraced in each state. The federal legal framework for drug prohibition provides discretion to state and local governments to employ different methods for controlling drug distribution and use. ${ }^{65}$ While a majority of states historically embraced the prohibitionist model of drug control, a growing number of states have recently adopted alternative drug control schemes. ${ }^{66}$ To date, twenty-three states and the District of Colombia have enacted laws to legalize the medical use of cannabis. ${ }^{67}$ In most recent developments, the states of Colorado and

59. KINGS COUNTY BAR, supra note 36, at n.174. The Nixon administration's anti-drug activities included increased border searching on the Mexican border, the creation of the National Commission on Marijuana and Drug Abuse in 1971. KINGS CounTY BAR, supra note 36 , at n. 174 .

60. 21 U.S.C. $\S 801$ (2013).

61. Kings COUNTY BAR, supra note 316 , at n.175.

62. Office of National Drug Control Policy, National Drug Control Strategy, ch. IV, pt. 7 (1999), archived at http://perma.cc/9VJR-S66N.

63. Controlled Substances Act Summary, Uniform LAW COMmission, http://www.uniformlaws.org/ActSummary.aspx?title=Controlled $\% 20$ Substances $\% 20$ Act (last visited Aug. 30, 2014, archived at http://perma.cc/94R8-VBY8).

64. 21 U.S.C. $\S 801$ (2013).

65. Kings COUNTY BAR, supra note 36 , at 70.

66. Federal law establishes a blanket prohibition of narcotics listed on the CSA schedules. By creating local laws to legalize some of these substances, a conflict is created over federal power and states' rights. KINGS COUNTY BAR, supra note 36, at 93. This conflict implicates the Commerce and Supremacy Clauses of the United States Constitution. Id. For an in-depth discussion of this conflict, see KINGS COUNTY BAR, supra note 36, at 178-187.

67. 23 Legal Medical Marijuana States and DC, ProCon.org, http://medicalmarijuana.procon.org/view.resource.php?resourceID $=000881$ (last updated July 31, 2014, archived at http://perma.cc/9KX7-TXYN). 
Washington passed initiatives legalizing the personal use, possession, and production of cannabis. Whether these divergent state laws will be upheld under the federal drug control statutes and the United States Constitution remains an open question.

\section{US Foreign Policy and International Drug Control Activity}

The United States also engages in a number of international activities aimed at decreasing the international flow of illicit drugs, including "eradicating crops and production activities, combating drugs in transit, dismantling international illicit drug networks, and creating incentives for foreign government cooperation on U.S. drug control initiatives." ${ }^{\text {" }} 8$ The United States engages in numerous bilateral agreements with drug producing countries to support training and equipping military personnel with attack helicopters, weapons, and other equipment to be used in the fight against drug trafficking. ${ }^{69}$ Significant federal resources are appropriated for these ends. For instance, between 2000 and 2005 the United States Congress allocated $\$ 4.3$ billion to fight the drug trade in the Andean region. ${ }^{70}$ In 2008, the United States provided $\$ 400$ million in foreign-assistance packages to the Mexican government to combat drug trafficking in Mexico. ${ }^{71}$

The United States employs a number of specific strategies in its international fight against drugs. "Aid leveraging" tactics are used as a tool for stimulating and maintaining drug enforcement programming in foreign nations. ${ }^{72}$ In 1986, Congress passed amendments to the Foreign Assistance Act for the suspension of economic aid to countries not cooperating with US prohibition efforts. ${ }^{73}$ The Anti-Drug Abuse Act created a certification system allowing the United States to "use foreign economic aid to pressure foreign governments to establish domestic drug control measures." ${ }^{\text {"74 }}$ Also, the president may act under the US Foreign Relations Authorization Act to waive financial aid commitments for any country designated as having "failed demonstrably" to make substantial efforts to adhere to international counter-narcotics agreements. $^{75}$ In addition, US representatives to

68. WYLER, supra note 24, at "Summary."

69. Marshall B. Lloyd, Conflict, Intervention, and Drug Trafficking: Unintended Consequences of United States Policy in Colombia, 36 OKLa. City U. L. ReV. 293 (2011).

70. Conne Veillette \& Carolina Navarrete-Frías, Cong. Research Serv., RL 33163, Drug Crop Eradication and Alternative Development in the Andes 1 (2005), archived at http://perma.cc/PP5Z-M6X7.

71. Lloyd, supra note 69, at 314.

72. Sandi R. Murphy, Drug Diplomacy and the Supply-Side Strategy: A Survey of United States Practice, 43 VAND. L. REV. 1259, 1266 (1990).

73. Hallums, supra note 4 , at 843 .

74. Hallums, supra note 4, at 843-844.

75. United States Dep't of State Bureau for Int'L Narcotics and Law 
multilateral development banks (e.g., the World Bank and Inter-American Development Bank Group) vote against multilateral loans for any country not receiving certification from the president. ${ }^{76}$ Free trade agreements such as the US-Andean Trade Promotion and Drug Eradication Act are also used to encourage anti-drug programming in drug producing countries. ${ }^{77}$

Aid leveraging facilitates US-sponsored crop eradication programs that aim to attack the drug supply at its agricultural foundation. For example, Bolivia, a drug-producing country dependent on foreign aid for its agricultural and economic development, found cooperation with US drug enforcement efforts to be a political and economic necessity. Since the 1970s, the United States has encouraged Bolivian coca controls through the promulgation of several bilateral agreements and financial assistance packages. ${ }^{78}$ In 1983 Bolivia agreed to meet drug eradication targets in consideration for a foreign aid offer made by the US government. ${ }^{79}$ The United States cancelled this package when Bolivia failed to meet those eradication targets. ${ }^{80}$ In an effort to regain economic assistance, Bolivia ultimately cooperated with US military operations to destroy cocaine laboratories, and agreed to a total ban on coca production in Bolivia. ${ }^{81}$

US crop eradication methods vary by region and crop species. Aerial fumigation campaigns are used to reduce coca cultivation in Colombia, and involve the dispersion of harmful chemical herbicides from low-flying aircraft. ${ }^{82}$ Since 2000 , the United States has spent over $\$ 500$ million fumigating more than one million hectares of Colombian territory. ${ }^{83} \mathrm{Such}$ missions are conducted by US contractors, hired by the US Office of Interregional Aviation Support, and the Colombian National Police. ${ }^{84}$ Manual eradication techniques are also employed in some regions, involving teams of eradicators to pull coca bushes from the ground.$^{85}$ Such

Enforcement AfFairs, International NARCotics Control Strategy Report 2 (2012), archived at http://perma.cc/D3TW-SKW4.

76. Murphy, supra note 72, at 1266.

77. Ashley Day Drummond, Peru: Coca, Cocaine, and the International Regime Against Drugs, 14 L. \& Bus. Rev. Am. 107, 127 (2008).

78. Hallums, supra note 73 , at 827.

79. Murphy, supra note 72 , at 1276.

80. Murphy, supra note 72, at 1276.

81. Murphy, supra note 72, at 1276.

82. Veillette \& Navarrete-Frias, supra note 70, at 4 . A report by the Inter-American Drug Abuse Control Commission concluded that glyphosate poses a "significant risk to human health." InTER-American Drug Abuse Control Commission, ENVIRONMENTAL and Human Health Assessment of the Aerial Spray Program for Coca and Poppy CONTROL IN COLOMBIA 121 (2005), archived at http://perma.cc/6HMR-83J5.

83. See Human Rights Watch, Open Society Institute, Int'l Harm Reduction Ass'n,, Human Rights and Drug Policy: Briefings fOR the UN COMmission ON NARcotic Drugs 24 (2010) [hereinafter Human Rights AND Drug Policy], archived at http://perma.cc/5XK9-3KHD.

84. VeILlette \& NAVARRETE-Frías, supra note 70 , at 4.

85. Eradicators are often accompanied by police or military personnel. HUMAN RIGHTS 
techniques are routinely employed for coca eradication in a number of Andean nations and also in Afghanistan for the destruction of poppy crops. ${ }^{86}$ In an effort to mitigate the negative effects of crop eradication, the United States often promotes alternative crop substitution programming to replace illicit crops with legal alternatives. ${ }^{87}$ In practice, however, alternative crop programs fail to effectively reduce crop production and ultimately leave farmers without viable alternatives to drug production. ${ }^{88} \mathrm{In}$ some cases, eradication and substitution programs even lead to increased cultivation of drug producing crops in other locations. ${ }^{89}$ For example, eradication strikes in the Golden Triangle were shown to cause large increases in opium production in Afghanistan. ${ }^{90}$ As one Colombian farmer noted, "[u]ntil there is investment to change the foundation of our economy, people will continue to plant and replant coca, cutting down forests and doing what it takes to grow the only product that is easy to bring to market, always has a buyer, and generates an income to provide for a family." 91

Despite these crop eradication efforts, evidence indicates that aid leveraging and crop eradication initiatives fail to effectively decrease the production and trafficking of narcotic substances. Prohibitionist drug control programs simply provide an effective opportunity for the United States to perpetually exploit the economic positions of developing countries and incentivize impoverished peoples to become ever more invested in the risky yet highly profitable illicit drug trade.

\section{ANALYSIS}

While the modern drug control system may reduce the impact of some harms associated with narcotic drugs, it is arguable that prohibitive drug controls create additional costs and consequences for many peoples. Assessing the balance of these costs and benefits is essential to affecting appropriate drug control measures and minimizing the negative impacts of drugs in society. Unfortunately, the analyses routinely employed by drug control policymakers incorporate biased information and illogical reasoning founded predominantly on inaccurate data and subjective moral opinions. ${ }^{92}$ Oftentimes, the real and practical effects of drug controls are not wholly and equally considered. Indeed, "government agencies have sometimes

AND DRUG POLICY, supra note 83, at 23.

86. Human Rights and Drug Policy, supra note 83, at 23.

87. Swanson, supra note 7, at 793-794.

88. See Human Rights And Drug Policy, supra note 83, at 23.

89. Swanson, supra note 7, at 795.

90. Heilmann, supra note 6, at 268.

91. Human Rights ANd DRug Policy, supra note 83.

92. See generally Eric Blumenson \& Evan Nilsen, No Rational Basis: The Pragmatic Case for Marijuana Law Reform, 17 VA. J. Soc. PoL'Y \& L. 43 (2009) (concluding that US drug policies fail to meet its primary objectives: to respect citizen's rights, target real risks or harms, and be successful in reducing those risks and harms). 
used drug research to support policy rather than to shape it." 93

In order to promote efficiency and effectiveness in a given drug control regime, policymakers must accurately consider and compare all costs and benefits of the drug control system as well as the costs and benefits of drug use itself. Specifically, policymakers must comprehensively account for all positive and negative externalities associated with the production, consumption, and regulation of drugs. As economist Jeffrey Miron has suggested, determining the proper drug control system depends on (1) what level of reduction in drug consumption is actually beneficial to society, and (2) whether the prohibition policy itself is an effective method of achieving those reductions. ${ }^{94}$

\section{A. The Costs and Benefits of Drug Consumption}

It cannot be denied that people often derive a substantial short-term benefit from consuming narcotic substances, despite their high prices and the threat of severe penalties. ${ }^{95}$ Accordingly, a comprehensive analysis of the drug problem must appropriately account for this benefit when balancing the costs and benefits of drugs in society. Of course it could be argued that some drug users by their very nature underestimate the costs and consequences of addictive drug use. However, substantial evidence indicates that the negative consequences of narcotic drug use are often overstated: "the degree to which illegal drugs are physically detrimental is far less than generally portrayed, provided they are consumed under safe circumstances." Research also shows that many illicit drugs are "far less addictive than commonly portrayed," and that drug use does not necessarily result in decreased levels of personal health or productivity. ${ }^{97}$ In fact, several studies indicate that most regular drug users are capable of functioning normally as productive members of society and that their greatest drug-related problem is simply obtaining a steady supply. ${ }^{98}$

93. National Commission on Marijuana and Drug Abuse, Drug Use in America: Problem in Perspective 279, 368-70 (1973); The Commission on Marijuana and Drug Abuse, informally known as the "Shafer Commission" was created by the Nixon Administration. Despite these findings presented by the Commission, President Nixon disowned the Commission's report because it "would send the wrong message." Blumenson \& Nilsen, supra note 92, at 55-56.

94. Miron \& Zwiebel, supra note 30, at 181.

95. Miron \& Zwiebel, supra note 30 , at 182.

96. Miron \& Zwiebel, supra note 30, at 182.

97. "Few persons who try drugs or regularly use drugs become dependent." A. Thomas McLellan et al., Drug Dependence, a Chronic Medical Illness: Implications for Treatment, Insurance, and Outcomes Evaluation, 284 J. AM. MED. Ass'N 1689, 1693 (2000), archived at http://perma.cc/8M3D-7LDS; see generally Miron \& Zwiebel, supra note 30, at 182.

98. Charles Winick, Social Behavior, Public Policy, and Nonharmful Drug Use, 69 MilbanK QuARTERLy 437 (1991). 
Of course, this view of drug consumption as a largely harmless activity is not always accurate. Many individuals unavoidably maintain an imbalanced relationship with narcotic substances that often jeopardizes their health and productivity. Nonetheless, it remains clear that any "objective evaluation of prohibition ... should include any reduction in rational drug consumption" as a cost of the prohibition regime. ${ }^{99}$ Yet even when drug consumption is a rational decision and a benefit to the individual consumer, such activity may still cause harm to innocent third parties and society at large. Indeed, individual drug consumption often generates negative externalities, ${ }^{100}$ implying that the socially optimal level of drug consumption is less than any individually optimum level might be.

Although often overstated, the negative externalities of drug use are significant in some cases. For instance, drug use increases healthcare costs, including expenditures for drug abuse treatment and victims of drug-related crime. ${ }^{101}$ In fact, drug-related incidents in the United States are estimated to cost $\$ 11$ billion annually. ${ }^{102}$ Approximately two million emergency room visits in 2009 were the result of illicit drug use. ${ }^{103}$ Some might also suggest that the immorality of drug consumption justifies taking a hardline stance against drug use. Although a discussion of the morality of drug consumption is outside the scope of this Article, it suffices to note that a prohibitionist system "is not the only policy that can send a message about society's disapproval of drug consumption." 104 In weighing the effects of drugs and drug controls, moralists must account for the many costs created by prohibitive control regimes and consider the ethical responsibility governments have to minimize those consequences.

It is important to acknowledge that the costs derived from drug use are substantially separate and distinguishable from the costs created by drug prohibition. Prohibitionist controls cause many negative social effects including increased crime rates, prison overpopulation, and overburdened social services. Governments and independent organizations are unable to provide treatment and prevention services to drug users. As a result, many drug-related health problems result, including the spread of disease, preventable drug-related illnesses, and deaths resulting from overdose. Ultimately, many of the harms created by drug consumption are directly attributable more to the prohibitionist controls than the act of drug consumption, itself.

99. The Economics of Drug Prohibition, supra note 1, at 844.

100. Miron \& Zwiebel, supra note 30, at 183.

101. Miron Critique, supra note 28, at 5.

102. United States Dep't of Justice, Nat'L Drug Intelligence Ctr., National Drug ThrEAT ASSESSMENT 20114 (2011), archived at http://perma.cc/89ZU-C4N9 [hereinafter NDIC].

103. Id. at 3 .

104. The Economics of Drug Prohibition, supra note 31, at 847. 


\section{B. The Costs and Benefits of Drug Prohibition}

Advocates of prohibition often claim that crime is a direct consequence of drug consumption, ${ }^{105}$ implying that prohibition serves to reduce crime to the extent that it reduces drug use. However, empirical studies show there is a lack of causal connection between the tendency to commit crime and the tendency to use drugs. ${ }^{106}$ Instead, it is likely the prohibition policies themselves that breed most drug-related violence. In fact, prohibition is shown to cause an increase in income-generating crime rates such as theft and prostitution. ${ }^{107}$ Also, fluctuations in the US homicide rate over the past century correlate positively with enforcement of drug prohibition laws. ${ }^{108}$ Such studies indicate that many social ills commonly associated with narcotic drugs do not come from the actual use of drugs, per se, but rather from users' struggle to obtain illicit drugs and evade law enforcement.

Regardless, prohibitionist drug policies may be furthered because some individuals and entities are positioned to derive great benefit from their maintenance. Politicians who endorse prohibition can quickly gain political ground by criticizing opponents who endorse less restrictive alternatives. Also, participants in the healthcare and pharmaceutical industries profit from the illegality "of [narcotic] goods easily substitutable for their own." 109

Nonetheless, the primary justification of drug prohibition is its purported effect of limiting the drug supply and reducing the overall demand for drugs. ${ }^{110}$ However, evidence largely indicates that prohibitionist policies fail to achieve their stated objectives of reducing drug consumption and production. ${ }^{111}$ Economists suggest that because the demand for drugs is relatively inelastic, any prohibition-induced shift in supply has a relatively small affect on the quantity of drugs consumed. ${ }^{112}$ Indeed, empirical evidence indicates that prohibition is ineffective at reducing drug consumption by any significant margin; in the United States, drug prices have been stable or declining despite continuous increases in prohibitionist

105. MIRON CRITIQUe, supra note 28, at 12.

106. MIRON CRITIQUe, supra note 28 , at 12 (emphasis added).

107. Miron CRITIQUe, supra note 28, at 12.

108. Miron CRITIQUe, supra note 28, at 12.

109. Miron CRITIQUe, supra note 28, at 12.

110. This result comes imposing legal penalties for possession, increasing greater uncertainty about product quality, and other costs and dangers associated with transactions in an illegal market.

111. Swanson, supra note 7, at 792; Seth Harp, Globalization of the U.S. Black Market: Prohibition, The War on Drugs, and the Case of Mexico, 85 N.Y.U. L. REV. 1661, 1667 (2010).

112. Miron \& Zwiebel, supra note 30, at 176; see also Swanson, supra note 7, at 792; Harp, supra note 111 , at 1669. 
efforts. ${ }^{113}$ Crop eradication efforts by the United States abroad merely serve to sporadically and temporarily prevent impoverished farmers from growing highly valued drug-producing crops. ${ }^{114}$ Aid leveraging is also largely ineffective in suppressing the overall production of drugs. For example, after the United States threatened to suspend economic aid to Turkey, the Turkish government agreed to implement specific supply reduction policies, which cause the Mexican supply of drugs to the United States to increase. ${ }^{115}$ In all, it is clear that, despite such efforts, illicit drugs remain a widely accessible and extremely profitable commodity in the world market.

It is apparent that US eradication efforts fail to eliminate or substantially reduce the production of illicit drug substances. But worse is the fact that prohibitive drug control policies impose a significant number of threats and negative effects on society. As the Secretary-General of the UNODC conceded, the continued operation of the prohibitive drug control regime has several "unintended consequences." 116 The following sections provide a brief overview of the commonly recognized costs of drug prohibition policies.

\section{Creation of a Black Market}

Prohibition policies effectively create a black market for narcotic substances by monopolizing the market for producers willing to assume the risks of illegal business. While millions of users are forced to obtain drugs through illicit means, drug traffickers continue to obtain enormously high profit margins. ${ }^{17}$ These high margins reflect the drug traffickers' willingness to assume significant risks associated with black markets operations, including potential criminal sanctions, violence, and death.

113. Keefer et al., supra note 3, at 6-7.

114. Raustiala, supra note 14, at 99-100. Eradication in one region merely displaces drug production to another. Swanson, supra note 7, at 792. For instance, while aerial eradication in Colombia has been shown to markedly reduce production in some target regions, such success is regularly accompanied by increased crop production in others areas. VEILLETTE \& NAVARRETE-FríAS, supra note 70, at 5. Also, decreased opium production in the Golden Triangle that resulted from stricter supply controls ultimately led to large increases in opium production in Afghanistan. Heilmann, supra note 6, at 268.

115. Murphy, supra note 72, at 1275. In fact, the US Department of Justice acknowledges that, despite significant government efforts to limit drug use, "[o]verall drug availability is increasing." NDIC, supra note 102, at 2 (alteration added).

116. See Heilmann, supra note 6, at 267-268. Many of these social ills are widely acknowledged in scholarship, media, and political discourse. See, e.g., Kevin Hartnett, From Small Corners to Big Cartels, the Drug War's Unintended Consequences, PenN. GazetTE (Oct. 28, 2009), http://www.upenn.edu/gazette/1109/gaz04.html, archived at http://perma.cc/976R-Y2K7; Ricky N. Bluthenthal, Collateral Damage in the War on Drugs: HIV Risk Behaviors Among Injection Drug Users, 10 InT'L J. DrUG POL'Y 25 (1999).

117. Blumenson \& Nilsen, supra note 92, at 49. 
Processed cocaine that is available in Colombia for $\$ 1,500$ per kilo sells for $\$ 66,000$ on the streets of the United States. ${ }^{118}$ A kilo of heroin selling for $\$ 2,600$ in Pakistan can be peddled for as much as $\$ 130,000$ in the United States. ${ }^{119}$ Meanwhile, drugs themselves remain unregulated, ${ }^{120}$ thus eliminating any chance for government control over purity, potency, labeling, advertising, or availability. Additionally, users of low-impact drugs (e.g., cannabis users) are forced to buy from criminal dealers who may also sell "harder" drugs (e.g., opiates), a phenomenon that increases the likelihood that the youth population will gain access to, and potentially abuse, harsher substances. $^{121}$

\section{Violence and Corruption}

Prohibition threatens the security and wellbeing of many peoples affected by the War on Drugs and increases the potential for violent crime. Without access to a state-sponsored dispute resolution forum, all transactions in the illicit drug market take place outside the traditional civil justice system, leaving violence as the primary dispute resolution mechanism. The prevalence of violence in the drug production industry encourages the creation of organized crime groups, which further increases incidents of crime, violence and death borne from drug related activities. Meanwhile, the supply of drugs to consumers remains constant: the only change is an increased price and reduced product quality. ${ }^{122}$ Prohibition also increases the prevalence of corruption by forcing market participants to conduct business illegally, thus incentivizing bribery and extortion of local officials, legislators, and judges in drug producing countries. ${ }^{123}$

118. These estimates reflect prices in the late 1990s, and are reflected in constant 1998 dollars. Oriana Zill \& Lowell Bergman, Do the Math: Why the Illegal Drug Business is Thriving, FroNTLINE (Jan. 12, 1998), http://www.pbs.org/wgbh/pages/frontline/shows/drugs/special/math.html, archived at http://perma.cc/V6CL-RN3K.

119. Id.

120. Blumenson \& Nilsen, supra note 92 , at 49.

121. Blumenson \& Nilsen, supra note 92 , at 7.

122. Harp, supra note 111 , at 1670.

123. Raustiala, supra note 14, at 100-01. In Peru, for example, corruption is pervasive throughout the political system, affecting almost seventy percent of all political dealings. TRANSPARENCY INT'L, REPORT ON THE TRANSPARENCY INTERNATIONAL GLOBAL CORRUPTION BAROMETER 200614 (2006), archived at http://perma.cc/P8BM-YSK8. In Mexico, transnational criminal organizations "have infiltrated every layer of society in Mexico," increasing incidences of narco-terrorism and drug-related violence throughout Central America. Harp, supra note 111, at 1676. See also Drummond, supra note 77, at 125. Highly organized and equipped with an arsenal of weaponry, these cartels routinely fight in street battles with government infantry, extort and murder public officials, and torture cartel enemies. Harp, supra note 111, at n.113. 


\section{Impaired Health}

Drug prohibition hinders drug treatment efforts and diminishes societal health. Prohibitionist control systems promote widespread fear of legal repercussions among drug users and so serve to discourage drug users from admitting their illegal use or seeking drug treatment. Criminalization of relatively low-impact drugs (e.g., cannabis) dramatically increases the number of drug offenders placed in the penal system, burdens drug treatment facilities with the care of low-impact drug users, and reduces the treatment space available for users of harder substances. ${ }^{124}$ Also, because drug prohibition has forced the street price for drugs to significantly increase, users are incentivized to switch to using cheaper yet more physically harmful synthetic drugs like methamphetamine and bath salts. ${ }^{125}$ Many times, these cheaper drugs are of a lower quality and create more serious and frequent health problems for users than non-synthetic drugs. ${ }^{126}$

\section{Productivity Loss}

Prohibition also affects productivity through the imposition of criminal penalties that impose significant lifelong burdens on individuals accused or convicted of drug-related crimes. Sanctions can include loss of professional license, barriers to employment opportunities, loss of financial aid for education, suspension of driver's license, and limits on adoption, voting and government service. ${ }^{127}$ Productivity in drug producing countries is further hindered by the pervasive violence that stems from drug control activities. Prohibition contributes to the weakening of social stability, stifles economic productivity, and promotes civil unrest in drug-producing countries by providing a source of income to rebel groups and fueling an underground battle for control of the transnational drug market. ${ }^{128}$

124. Blumenson \& Nilsen, supra note 92, at 52.

125. Abby Goodnough \& Katie Zezima, An Alarming New Stimulant, Legal in Many States, $\quad$ N.Y. Times (Jul. http://www.nytimes.com/2011/07/17/us/17salts.html?pagewanted=all, archived at http://perma.cc/7KMN-UAUX.

126. Blumenson \& Nilsen, supra note 92 , at 50.

127. See United States Government Accountability Office, Drug Offenders: Various Factors May Limit the Impacts of Federal Laws That Provide For Denial of SELECTED BenEFITS (2005). Every year approximately 17,000 to 20,000 students lose access to Pell Grants and 29,000 to 41,000 lose access to student loans. Id. at 12. As a result the, many low-income and minority individuals who lack alternative funding sources for education are prevented from obtaining higher education. $I d$. at 6 .

128. Miron CRITIQUe, supra note 28, at 14 . 


\section{An Important Consideration: Infringements on Developmental Rights}

In addition to these commonly recognized costs, this Article calls attention to an additional consequence of prohibitionist drug policy: the violation of developmental rights of peoples in drug producing countries. Prohibition creates particularly high social costs for many peoples, especially individuals living in countries involved in the international conflict over narcotic drugs. Beyond the violence and corruption-producing effects previously discussed, drug prohibition promotes civil unrest and economic oppression in drug producing countries that ultimately results in an infringement of developmental human rights.

The barriers to development created by prohibitionist policies are numerous. Public funds that may have been used for investments in health, education, and infrastructure development are instead allocated to the drug enforcement regime, including police, judiciary system, and prisons. Prohibition encourages the destruction of private property and expropriates the wealth of poor farmers involved with drug crop cultivation. ${ }^{129}$ Public safety and security are undermined, leaving entire national governments weakened by the plague of corruption and violence that accompanies the illicit drug industry.

"[D]rug controls are not an end in and of themselves ... the ultimate objective of drug control efforts is to improve public health and to limit human suffering." ${ }^{, 130}$ Unfortunately, extreme actions undertaken in the War on Drugs - including military operations against farmers, chemical crop eradication campaigns, and widespread imprisonment of drug users - have yielded human rights abuses, marginalized international security, and created barriers to sustainable global development. ${ }^{131}$

States are obligated to honor developmental rights in drug control policymaking and activities though the promulgation of treaties, peremptory norms (jus cogens), and customary international law. Such obligations are primarily established in the U.N. Charter; as the preeminent international treaty, the U.N. Charter makes binding on all states the protection and furtherance of human rights for all peoples. ${ }^{132}$ The Charter references human rights numerous times, listing among the purposes of the United Nations "international cooperation in promoting and encouraging respect for human rights." 133 Today, it is widely acknowledged that "a minimum

129. See Keefer et al., supra note 3, at 20.

130. Heilmann, supra note 6 , at 265.

131. Heilmann, supra note 6, at 265.

132. Heilmann, supra note 6 , at 270. Many view the U.N. Charter as the quasiconstitution of the international community "in the sense that it is a set of rules of international law which takes precedence over other norms because their existence is a precondition to the validity of the latter." Heilmann, supra note 6, at 270.

133. Heilmann, supra note 6 , at 270 . 
standard of human rights obligations exists that no State can ignore."134

The international community widely recognizes the right to development as a fundamental human right that integrates economic, social, and cultural rights with civil and political rights. ${ }^{135}$ The United Nations Universal Declaration of Human Rights and the United Nations Declaration on the Right to Development (the Declaration), agreements that have both been widely adopted among U.N. member States, unequivocally proclaim the validity of the human right to development. ${ }^{136}$ As a fundamental human right, State recognition of the developmental right requires that the State provide positive conditions for peoples to fully participate in the affairs of society. ${ }^{137}$

Specific protections afforded by developmental rights are outlined in the text of the Declaration. Article 1 of the Declaration states: "The right to development is an inalienable human right by virtue of which every human person and all peoples are entitled to participate in and contribute to and enjoy economic, social, cultural, and political development in which all human rights and fundamental freedoms can be fully realized." ${ }^{\prime 38}$ States are widely bound to take joint and separate action to promote high standards of living, full employment, and conditions of economic and social progress of all peoples through the "creation of national and international conditions favourable [sic] to the realization of the right to development." 139

The Declaration also acknowledges peoples' right to selfdetermination, and recognizes the "human person" as "the active participant and beneficiary of the right to development." 140 The right to development harbors for all peoples the opportunity to equally participate in "a particular process of development in which all human rights and fundamental freedoms can be fully realized," and requires implementation of transparent and accountable systems that afford equal opportunity of access to the resources necessary for development. ${ }^{141}$

Recognition of these protections necessarily creates an affirmative responsibility on States to create "national and international conditions favorable to the realization of the right to development." $" 142$ Indeed,

134. Heilmann, supra note 6 , at 270.

135. Arjun Sengupta, The Right to Development as a Human Right, 36 Econ. \& Pol. Wkly. (1999).

136. Id. at 1.

137. The United States is the only U.N. Member State that has not yet ratified the Declaration. Id. at 2.

138. Declaration on the Right to Development, U.N. Doc A/RES/41/128 art. 1 (Dec. 4, 1986).

139. Id. art. 3.

140. Id. art. 2, cl. 1.

141. Sengupta, supra note 135 , at 5 .

142. Declaration on the Right to Development, U.N. Doc A/RES/41/128 art. 3 (Dec. 4, 1986). 
international cooperation is a fundamental requirement inscribed throughout the Declaration, proclaiming that "all states should co-operate with a view to promoting, encouraging and strengthening universal respect for and observance of all human rights and fundamental freedoms." ${ }^{143}$ Article 3 notes that "the realization of the right to development requires full respect for the principles of international law concerning friendly relations and cooperation among States in accordance with the Charter of the United Nations." 144 Thus, States are obliged to work cooperatively toward the elimination of "flagrant violations of human rights," such as foreign domination and occupation. ${ }^{145}$ It follows that the Declaration encourages States to design and adopt policies that do not hinder the developmental process for all peoples.

Although the United States has not yet ratified the Declaration, US obligations to protect developmental rights are firmly established in customary international law and the norms of jus cogens. These customary legal obligations are derived from the consistent practice of a significant number of States, including the United States, which foster continued economic development in drug producing nations. ${ }^{146}$ In a sense, customary law is "nontreaty law generated through consistent practice accompanied by a sense of legal obligation." "147 Early interpretations of the right to development extended customary legal status to only a handful of protections, including "slavery, genocide, arbitrary killings," and the like. ${ }^{148}$ But today, "a compelling argument can be made that a significant range of socioeconomic rights have acquired the status of customary law."149

The United States actively demonstrates a clear commitment to promoting economic progress in developing nations. The 1961 Foreign Assistance Act permits the president to provide assistance to extend economic and technical aid to rural farmers of foreign nations "to provide a more viable economic base and enhance opportunities for improved incomes, living standards, and contributions by rural poor people to the economic and social development of their countries." ${ }^{150}$ Interestingly, the Act also stipulates that aid will not be provided to any nation that "engages in a consistent pattern of gross violations of internationally recognized

\footnotetext{
143. Id. art. 6 .

144. Id. art. 3, cl. 2 .

145. Id. art. 5.

146. Customary International Law, USLEGAL.COM, http://internationallaw.uslegal.com/sources-of-international-law/customary-internationallaw/ (last visited Mar. 2, 2014, archived at http://perma.cc/4ZZS-GQAE).

147. Mac Darrow \& Louise Arbour, The Pillar of Glass: Human Rights in the Development Operations of the United Nations, 103 AM. J. INT'L L. 446, 470 (2009).

148. Id.

149. Id.

150. 22 U.S.C. $§ 2151$ (a) (2000).
} 
human rights . . . including torture or cruel, inhuman, or degrading treatment or punishment . . causing the disappearance of persons . . . or other flagrant denial of the right to life, liberty, and the security of person." 151

Several agencies were created under the Foreign Assistance $\mathrm{Act}^{152}$ to administer foreign aid, including the US Agency for International Development (USAID). Presently, USAID promotes "broad-based economic growth by addressing the factors that enhance the capacity for growth and by working to remove the obstacles that stand in the way of individual opportunity." 153 USAID specifically addresses the economic crises borne from US antinarcotics efforts by promoting "sustainable and equitable economic growth opportunities in regions vulnerable to drug production and conflict." 154

Despite these clear commitments of the United States to improving economic conditions abroad, US drug prohibition affirmatively stifles economic growth and violates developmental rights for many peoples in drug-producing countries. Prohibition puts "money in the pockets of criminals and armed groups" and erodes the democratic protections of the people most closely affected by the War on Drugs. ${ }^{155}$ Punitive drug laws facilitate disappearances, inhumane treatment, and extrajudicial killings of drug market participants. ${ }^{156}$ Increased corruption and violence occurs against drug traffickers, politicians, police, judges, and armed forces, fueling the depletion of State authority, regional stability, and social security for many peoples in drug producing countries. ${ }^{157}$

151. 22 U.S.C. $\S 2304(a)(2)$, (d)(1) (2013).

152. 22 U.S.C. $\S 2151$ et seq.

153. National Archives and Records Administration, Office of the Federal Register, The United States Government MANuAl 482-85 (2013), archived at http://perma.cc/R6P6-F2BC (section on United States Agency for International Development).

154. U.S. Dept. of State \& U.S. Agency for InT'L DeV., Joint Summary of Performance AND FinANCiAl Information: Fiscal Year 201033 (2011), archived at http://perma.cc/HK2W-PB3Y.

155. Jonathan Glennie, Drugs are a Development Issue - Which is Why We Should Legalise Them, THE GUARDIAN (Oct. 5, 2010), http://www.theguardian.com/globaldevelopment/poverty-matters/2010/oct/05/drugs-prohibition-development-issue-legalisation, archived at $\mathrm{http}: / /$ perma.cc/5C56-SMXB.

156. Transform Drug Policy Foundation, The War on Drugs: Undermining INTERNATIONAL DEVELOPMENT AND SECURITY, INCREASING CONFLICT, archived at http://perma.cc/WF5H-HS72; Neither Rights Nor Security: Killings, Torture, and Disappearances in Mexico's “War on Drugs," Human Rights Watch (Nov. 9, 2011), http://www.hrw.org/reports/2011/11/09/neither-rights-nor-security, archived at http://perma.cc/X7EY-52CX.

157. Count THE COSTS, THE WAR ON DRUgS: Undermining INTERNATIONAL DEVELOPMENT AND SECURITY, INCREASING CONFLICT (2011), archived at http://perma.cc/XU59-ZRYF. 
Furthermore, crop eradication efforts strip farmers of their private property and threaten local ecosystems, biodiversity, and the health of indigenous and small farming communities. Imprecise aerial spraying and unavoidable crosswinds often cause the herbicides to drift into non-target areas, resulting in the destruction of licit crops and contamination of water sources. ${ }^{158}$ Significant forest contamination can and does result, causing loss of habitat for many species and posing a serious threat to the health of local peoples and the surrounding ecosystems. ${ }^{159}$ Health impacts of glyphosate are significant, including impairment of the nervous system (dizziness, headaches), digestive system (nausea, abdominal pains, diarrhea), and skin (sores, ulcers). ${ }^{160}$ Hospitals near the eradication sites report "increased visits for skin problems, abdominal pain, diarrhea, gastrointestinal infections, acute respiratory infection, and conjunctivitis following spraying in rural areas surrounding their municipalities."161

\section{PROPOSED SOLUTIONS}

It is clear that the US drug control system and its war against drugs facilitates broad human rights abuses, threatens international security, and "builds barriers to sustainable development." 162 The burdens created by the US drug control regime must be lifted from the shoulders of the peoples whose most viable economic opportunities lie in the cultivation of their indigenous crops. Pursuant to its obligations in international law, US policymakers must pursue a more balanced drug control policy that comprehensively considers all human rights, including the developmental rights of peoples in drug producing countries.

To this end, drug controls must be measured not by the quantity of drugs consumed, but instead by their impacts on quality of life and health for all affected people. The United States must act pursuant to the United

158. "Aerial spraying in some cases has inadvertently drifted onto crops such as coffee, yucca, and rice." Judith Walcott, Spraying Crops, Eradicating People, CulturAl SURVIVAL (May 5, 2010), http://www.culturalsurvival.org/publications/cultural-survivalquarterly/spraying-crops-eradicating-people, archived at http://perma.cc/95NN-4RSV.

159. The United States Environmental Protection Agency ranked glyphosate as the third most injurious pesticide. U.S. Envtl. Prot. AgenCy, Reregstration Eligibility Decision (RED): GlyphosAte 22 (1993), archived at http://perma.cc/S44K-T4SZ. A report by the Inter-American Drug Abuse Control Commission concluded that glyphosate poses a "significant risk to human health." Dr. KeIth R. Solomon ET AL., INTER-Am. Drug AbuSE Control Comm'n, Environmental and Human Health Assessment of the Aerial Spray Program for Coca AND Poppy CONTROL IN Colombia 121 (2005), archived at http://perma.cc/Q5TZ-T35L; see also Danielle Knight, Plan Colombia: Fumigation Threatens Amazon, Warn Indigenous Leaders, SCIENTISTS (Nov. 21, 2000), archived at http://perma.cc/4JTM-LUZU.

160. Id.

161. Walcott, supra note 158.

162. Heilmann, supra note 6, at 265. 
Nations Charter and Universal Declaration of Human Rights to promote full participation of all peoples in the affairs of society. ${ }^{163}$ Efforts must be refocused on reducing demand for the most hazardous drugs, aiding the most vulnerable populations, and generally seeking to minimize the individual and societal damage produced by drugs and drug controls alike.

In order to effectuate such changes, practical and realistic modifications must be made to the US prohibitionist control system. Many commentators suggest that widespread legalization of drugs in the United States is a viable option for reducing the problems of drug prohibition. ${ }^{164}$ As economist and prohibition expert Jeffrey Miron suggests, "Given the evidence . . . a free market in drugs is likely to be a far superior policy to current policies of drug prohibition." ${ }^{" 165}$ However, complete legalization of narcotics at the federal level is simply not a realistic proposition in today's political climate. ${ }^{166}$ Many policymakers fear that a relaxation of prohibitionist controls would lead to an increase in drug abuse in the short term and possibly a significant increase in drug-related problems in the long run. Some also suggest that "legalization would send the wrong message to children and encourage [drug use] by making [drugs] more readily available." ${ }^{\prime 67}$ Despite these contentions, it remains clear that the global consequences of drug prohibition necessitate a sizable policy revision.

As a practical suggestion, this Article proposes that US decisionmakers embrace a federal policy of controlled legalization of the least harmful illicit drugs that are commonly consumed in the United States. For instance, nationwide legalization of cannabis would serve to alleviate a portion of the problems created by drug prohibition without causing great disruption to social stability.

Under the current federal drug laws, cannabis is designated as a Schedule I controlled substance, a category of drugs reserved for substances with a high potential for abuse and no government-acknowledged medical use. Nonetheless, cannabis remains the world's most widely used illicit substance. ${ }^{168}$ In 2007, there were an estimated 160 million cannabis users worldwide, compared to just forty million users of amphetamines, cocaine,

163. Blumenson \& Nilsen, supra note 92, at 54.

164. Miron \& Zwiebel, supra note 30 , at 190.

165. Miron \& Zwiebel, supra note 30, at 190.

166. Miron does not suggest that full legalization is the only policy alternative, but rather that "given the evidence... a free market in drugs is likely to be a far superior policy to current policies of drug prohibition." Miron \& Zwiebel, supra note 30, at 190. Economists suggest that under a legalized system, the prevalence of cocaine consumption is likely to increase by 50 to 80 percent. Keefer et al., supra note 3, at 17 .

167. Cynthia S. Duncan, The Need for Change: An Economic Analysis of Marijuana Policy, 41 ConN. L. ReV. 1701, 1708-1709 (2009).

168. Beau Kilmer \& Rosalie liccardo Pcula, Rand Corporation, Technical Report: Estimating the Size of the Global Drug Market (Report 2) 10 (2009), archived at $\mathrm{http}: / /$ perma.cc/BNM3-8N7R. 
and opiates combined. ${ }^{169}$ This high rate of cannabis use, combined with the prohibitionist restrictions imposed on the cannabis market, contributes significantly to the social problems commonly attributed to drug consumption in the United States. Estimates suggest that the total current expenditures for US cannabis-prohibition enforcement efforts alone exceed $\$ 8$ billion annually. ${ }^{170}$ Despite these efforts to eliminate its production and consumption, cannabis remains widely available and regularly supplied by transnational criminal organizations.

Although opponents of legalization maintain that cannabis is a harmful substance void of any beneficial use, ${ }^{171}$ many negative perceptions of cannabis have been scientifically refuted in recent years. Medical research indicates that cannabis is not physically addictive and does not have significant negative health consequences, even when consumed in large doses. ${ }^{172}$ Also, an increasing number of medical authorities acknowledge the therapeutic and medicinal value of cannabis. ${ }^{173}$ Research from many countries indicates that cannabis serves as a market substitute for other drugs and dampens the use and effects of alcohol, tobacco, and other more harmful and dangerous drugs. ${ }^{174}$ The misconception that cannabis is a "gateway drug" has also been widely refuted by experts. Under a prohibition control system, cannabis can only be acquired for recreational use by purchasing from individuals providing access to harder drugs. ${ }^{175}$ However, it is not "[cannabis] use that leads to harder drugs, but the method of acquisition." ${ }^{176}$ A controlled and regulated cannabis market would provide the millions of US cannabis users with a legitimate supply and further isolate the distributors of harsher substances from the many cannabis consumers.

Cannabis legalization would result in immediate savings of billions of dollars for local, state, and national governments. Police and judicial systems would no longer arrest and prosecute individuals for cannabis

169. Heilmann, supra note 6 , at 262. Mexico alone produces more than ten million kilograms of marijuana annually for supply to the United States. Duncan, supra note 167, at 1715 .

170. Duncan, supra note 167 , at 1712 .

171. Duncan, supra note 167 , at 1706.

172. Miron \& Zwiebel, supra note 30, at 187; Duncan, supra note 167, at 1706, n.18.

173. Duncan, supra note 167 , at 1707 . Scientific evidence suggests that cannabis provides relief for several ailments and "alleviates symptoms of glaucoma, epilepsy, multiple sclerosis, AIDS, and migraine headaches." MIRON CRITIQUE, supra note 28, at 15.

174. Kenneth W. Clements \& Mert Daryal, The Economics of Marijuana CONSUMPTION 33-34 (1999), archived at http://perma.cc/FAG6-9K7V; Duncan, supra note 167 , at 1707. Scientific evidence suggests that cannabis provides relief for several ailments and "alleviates symptoms of glaucoma, epilepsy, multiple sclerosis, AIDS, and migraine headaches." MirOn CRITIQUe, supra note 28, at 15.

175. Duncan, supra note 167 , at 1708.

176. Duncan, supra note 167, at 1707. 
cultivation, sale, or possession. The US state and federal expenditures aimed at prohibiting cannabis - currently estimated at more than $\$ 8$ billion per year - would be virtually eliminated. ${ }^{177}$ Controlled legalization would also encourage domestic cannabis production and provide a foundation for the development of a new licit economy dedicated to the production and sale of cannabis. A controlled system of cannabis legalization would allow for the taxation and regulation of the cannabis market, including income and sales taxation, OSHA mandates, and environmental and labor market regulations. ${ }^{178}$ Such taxation would "generate billions of dollars for our state and local governments to fund what matters most: jobs, healthcare, school and libraries ... and more." 179

Most importantly, legalization of cannabis would significantly reduce the size and strength of criminal drug supply networks operating in the black market, and expand developmental opportunities for millions of individuals. Legalization would provide a licit supply source for cannabis and sizably reduce the demand for other illicit drugs. The transnational criminal supply networks for cannabis would be virtually eliminated, reducing cartel profits and corruption, leading to an overall decrease in violent incidents stemming from the illicit drug trade. Disputes between cannabis producers would be resolved through the state judicial system, further decreasing the prevalence of violence and corruption both domestically and abroad. A legitimate and regulated cannabis industry would provide employment opportunities and reduce many social and political implications of black market drug operations, including "corruption, violence, organized crime, and international arms trafficking." 180 Also, legalization would reduce the harsh impacts of criminal laws related to cannabis, particularly for low-income and minority cannabis users, and provide farmers in developing countries with a licit and viable crop alternative.

\section{CONCLUSION}

The failures of the US prohibitionist drug control system are apparent and undeniable. For decades, US drug prohibition efforts, both domestic and abroad, have fallen short of creating any meaningful reduction in the consumption of illicit drugs. Worse is the fact that these strict prohibitionist

177. Blumenson \& Nilsen, supra note 92, at 10.

178. Miron CritiQue, supra note 28, at 10. In 2009, Oakland, California became the first city in the US to directly tax cannabis by imposing a 1.8 percent gross receipt tax on medical cannabis sold in the city. Michelle Patton, The Legalization of Marijuana: A Dead-End or the High Road to Fiscal Solvency?, 15 Berkeley J. CRIM. L. 163, 169 (2010). This tax is expected to generate more than $\$ 400,000$ in annual revenue for the city. $I d$.

179. Id. at 188 .

180. Swanson, supra note 7 , at 793. 
policies consistently foster a multitude of social and economic difficulties for many peoples throughout the world. The system's costs are not adequately or wholly considered. Policymakers continually neglect the costs of these prohibitionist controls, and fail to equally and adequately account for their harsh impacts. US decision-makers view the foreign drug control efforts as necessary for ensuring the health and prosperity of US society. Improper emphasis is all too often placed on the deterrent and punitive forces of drug control measures. Worse still is the fact that state officials often overlook the developmental human right in drug policymaking, despite clear national commitments to uphold such right in the United Nations Universal Declaration of Human Rights and the United Nations Declaration on the Right to Development.

Lawmakers must pursue a more balanced drug control policy that comprehensively considers all human rights, including the developmental rights of peoples in drug producing countries. States must be held accountable for their commitments to uphold and honor all internationally recognized human rights, including the right to full participation in economic activities. The full participation of all peoples in the social and economic affairs of their societies should be fairly promoted and equally accounted in US policymaking.

Drug control efforts must be practically and fairly adjusted, and the policy focus must be set on aiding vulnerable populations and minimizing the damages created by government-imposed drug market controls. Policy should aim to reduce the market share and political strength of transnational criminal organizations, not merely to create temporary impediments to the inflow of drugs into the United States. To this end, ineffective measures should be adjusted or altogether abandoned. The time has come for US policymakers to realign their priorities in favor of promoting human rights both domestically and abroad to enlarge developmental opportunities for millions. 